\title{
Edukasi perencanaan menu dan ketepatan pemorsian berdasarkan prinsip gizi seimbang di panti sosial Tresna Werdha Budi Mulia 4 Cengkareng
}

\author{
Putri Ronitawati ${ }^{1, *}$, Prita Dhyani Swamilaksita ${ }^{2}$, Rachmanida Nuzrina ${ }^{3}$, Putri Nurhasanah Yahya ${ }^{4}$ \\ ${ }_{1,3}^{1,3}$ Prodi Pendidikan Profesi Dietisien, Fakultas Ilmu-Ilmu Kesehatan, Universitas Esa Unggul \\ ${ }^{2,4}$ Prodi Gizi, Fakultas Ilmu-Ilmu Kesehatan, Universitas Esa Unggul \\ Email Korespondensi: "putri.ronitawati@esaunggul.ac.id ${ }^{1}$
}

Received January 16, 2021; Revised April 6, 2021; Accepted April 13, 2021

\begin{abstract}
Abstrak
Asupan zat gizi pada lansia berbeda dengan kebutuhan ketika usia muda. Asupan zat gizi yang cukup serta seimbang pada lansia berguna untuk kelangsungan hidupnya di hari tua. Faktor yang belum diperhatikan yaitu, ketersediaan bahan makanan dipasar dan food habit serta preference yang masih kurang baik. Selain itu kurang memperhatikan ketersediaan bahan di pasar, evaluasi menu dan kebutuhan gizi lansia yang diperhitungkan. Namun di dalam pelaksanaannya, standar menu yang ada tidak selalu diterapkan terutama bila masih ada sisa bahan makanan kemarin dihidangkan lagi untuk hari selanjutnya, tetapi pada saat turun lapang seperti buah yang masih tersisa disediakan kembali dihari berikutnya walaupun hari itu buahnya bukan buah tersebut. Kegiatan pengabdian ini untuk memberikan edukasi mengenai pengetahuan perencanaan menu dan porsi yang sesuai bagi kebutuhan lansia kemudian dilanjutkan dengan pembinaan terkait perencanaan menu dan ketepatan pemorsian meliputi makanan khusus bagi lansia dengan penyakit tertentu, pengetahuan mengenai menu, ketepatan pemorsian pada menu yang disajikan pada pihak panti dan penjamah makanan dan membuat perencanaan menu yang baik untuk lansia sesuai standar di Panti Werdha Budi Mulia 4 Cengkareng. Melalui kegiatan pengabdian ini juga agar makanan yang disediakan untuk lansia bisa lebih bervariasi sehingga meningkatkan selera makan lansia.
\end{abstract}

Kata Kunci: gizi seimbang; lansia; pengetahuan perencanaan menu

Abstract
Nutritional intake in the elderly is different from the needs at a young age. Adequate and balanced nutritional intake in the elderly is useful for their survival in old age. Factors that have not been considered are the availability of foodstuffs in the market and poor food habits and preferences. Apart from that, it does not pay attention to the availability of ingredients in the market, the evaluation of the menu, and the calculated nutritional needs of the elderly. However, in practice, the existing menu standards are not always applied, especially if there are still leftovers from the previous day, it is served again for the next day, but when it comes down, the remaining fruit is provided again the next day even though that day the fruit is not the fruit. This service activity is to provide education regarding knowledge of menu planning and portions that are suitable for the needs of the elderly, then continued with guidance related to menu planning and accuracy of cooking including special food for elderly with certain diseases, knowledge of menus, the accuracy of cooking on the menu served to the orphanage food handlers and make good menu planning for the elderly according to the standards at the Budi Mulia 4 Cengkareng Nursing Home. Through this service activity, the food provided for the elderly can be more varied, thereby increasing the appetite of the elderly.

Keywords : balanced nutrition; elderly; menu planning

\section{PENDAHULUAN}

Menurut World Health Organisation (WHO), lansia adalah seseorang yang telah memasuki usia 60 tahun keatas. Lansia (lanjut usia) mulai mengalami perubahan fisik, biologis dan sosial yang akan mempengaruhi aspek kehidupannya. Asupan zat gizi pada lansia berbeda dengan kebutuhan ketika usia muda. Asupan zat gizi yang cukup serta seimbang pada lansia berguna untuk kelangsungan hidupnya di hari tua [1]. Status kesehatan seorang lansia sangat dipengaruhi oleh penilaian kebutuhannya akan zat gizi. Seorang lansia yang tergolong sehat juga dapat mengidap penyakit kronis. Kebutuhan asupan zat gizi pada lansia akan 
mengalami perubahan akibat meningkatnya morbiditas dan penyakit tidak menular seperti penyakit jantung koroner, tekanan darah tinggi, diabetes mellitus, serta penyakit kronis lainnya [2]. Lansia dengan gizi cukup, sehat, dan mampu untuk mandiri merupakan komponen dari kualitas hidup yang memadai. Perubahan pada rongga mulut lansia menyebabkan kurangnya asupan makanan yang beraneka ragam yang memungkinkan terjadinya kekurangan gizi [3]. Status gizi dan status kesehatan sangat ditentukan oleh kondisi yang dialami oleh lanjut usia. Status gizi dan status kesehatan yang baik akan membawa seseorang kepada umur panjang yang sehat dan produktif. Selain itu, status kesehatan pada lansia akan berpengaruh dalam penilaian kebutuhan akan zat gizi [4]. Dengan meningkatkan pelayanan gizi pada lanjut usia diharapkan dapat menanggulangi masalah gizi lanjut usia sehingga pada akhirnya dapat meningkatkan status gizi dan kesehatan lanjut usia.

Penyelenggaraan makan di panti werdha bertujuan untuk memenuhi kebutuhan lansia sehingga diperlukan penyusunan menu makanan yang dapat meningkatkan selera makan bagi lansia untuk memenuhi kebutuhan fisiologisnya. Keberhasilan suatu penyelenggaraan makanan di Institusi di tentukan oleh penerimaan makanan yang disajikan. Daya terima baik apabila sisa makanan yang disajikan <20\%. Menurut Nugroho, hal terpenting dalam pemberian makanan pada lansia adalah makanan yang disajikan harus memenuhi kebutuhan gizi, makanan yang disajikan diberi secara teratur dalam porsi sedikit tetapi sering, makanan harus bertahap dan bervariasi agar tidak menimbulkan kebosanan, makanan harus sesuai dengan petunjuk dokter bagi lansia tertentu dan makanan harus berbentuk lunak [5]. Salah satu hal terpenting dalam penyusunan makanan untuk lansia agar meningkatkan selera makan lansia. Kegiatan makan yang sehat meliputi pengaturan jumlah kecukupan makanan, jenis makanan dan jadwal makan, yang fungsinya untuk mempertahankan kesehatan. Dengan memperhatikan unsur-unsur tersebut, maka dibutuhkan penyusunan menu makanan bagi lansia. Menu bagi lansia hendaknya mengandung zat gizi dari berbagai macam bahan makanan yang terdiri dari zat tenaga, pembangun dan pengatur [6].

Penelitian Aspiyani di PTSW Budi Mulia 4 menunjukkan bahwa responden dengan kategori gizi baik sebanyak 14 responden (28\%), berisiko gizi kurang sebanyak 29 responden (58\%), dan gizi kurang sebanyak 7 responden (14\%). Pengukuran status gizi lansia menggunakan MNA dimana terdapat beberapa pertanyaan mengenai penurunan nafsu makan. Sebagian besar lansia mengalami penurunan nafsu makan dikarenakan kurangnya variasi menu makanan yang diberikan. Siklus menu yang digunakan di PSTW Budi Mulia 4 Cengkareng adalah siklus menu tujuh hari, buah diberikan hanya pada waktu makan siang. Siklus menu yang telah ada tidak diterapkan dengan baik, seperti halnya pada siklus menu terdapat buah dan snack, namun pada saat pengamatan buah yang disediakan tidak sesuai yang terdapat di menu dan terkadang tidak selalu ada snack yang disajikan. Pihak panti melakukan siklus menu sesuai hari dalam satu minggu atau tujuh hari tersebut. Dilihat dari siklus menu yang ditampilkan masih sering terjadi pengulangan penggunaan bahan makanan, selain itu juga variasi bahan makanan juga masih kurang diperhatikan, sehingga sering sekali bahan makanan yang sama digunakan pada waktu yang berdekatan hanya saja dibedakan dalam variasi teknik pengolahan atau memasak. Variasi bahan makanan pada menu hasil pengamatan dari siklus menu kurang bervariasi terutama pada lauk-pauk sumber protein hewani dan nabati seperti telur yang disajikan pada waktu makan pagi disajikan lagi pada saat makan sore, begitu pula dengan protein nabati seperti tempe dan tahu disajikan lagi pada saat waktu makan sore hanya saja cara pengolahan dan resep makanan yang berbeda, sehingga menimbulkan rasa bosan pada makanan yang disediakan.

Berdasarkan latar belakang permasalahan diatas, mendorong penulis untuk melakukan kegiatan pengabdian masyarakat yang dilakukan dengan memberikan edukasi mengenai perencanaan menu dan ketepatan pemorsian. Pada kegiatan ini juga penulis mengembangkan media edukasi yang inovatif berbentuk cakram menu, dimana dengan cakram menu ini diharapkan dapat membantu pengelola penyelenggara makanan PSTW Budi Mulia 4 dapat lebih mudah dalam penyusunan menu yang beragam dan bergizi seimbang untuk para lansia penghuni panti, meningkatkan kompetensi pihak pengelola dan penjamah makanan mengenai perencanaan menu yang baik serta ketepatan pemorsian yang sesuai bagi lansia.

\section{METODE}

Kegiatan program pengabdian masyarakat ini dengan melakukan pembinaan pada PSTW Budi Mulia 4 Cengkareng, khususnya pada pengelola panti dan penjamah makanan. Kegiatan ini dilakukan dengan menggunakan pre test dan post test terhadap pihak pengelola dan penjamah makanan. Kegiatan ini dilakukan terhadap pihak pengelola dan penjamah makanan adalah sebagai berikut:

1. Membuat perencanaan menu dan porsi yang sesuai (piring makanku) bagi lansia

2. Mengaplikasikan perencanaan menu dan porsi yang sesuai (piring makanku) dalam pembuatan media edukasi yang digunakan meliputi cakram menu seimbang bagi lansia

3. Melakukan intervensi berupa pembinaan dan edukasi kepada pihak pengelola panti dan penjamah makanan 


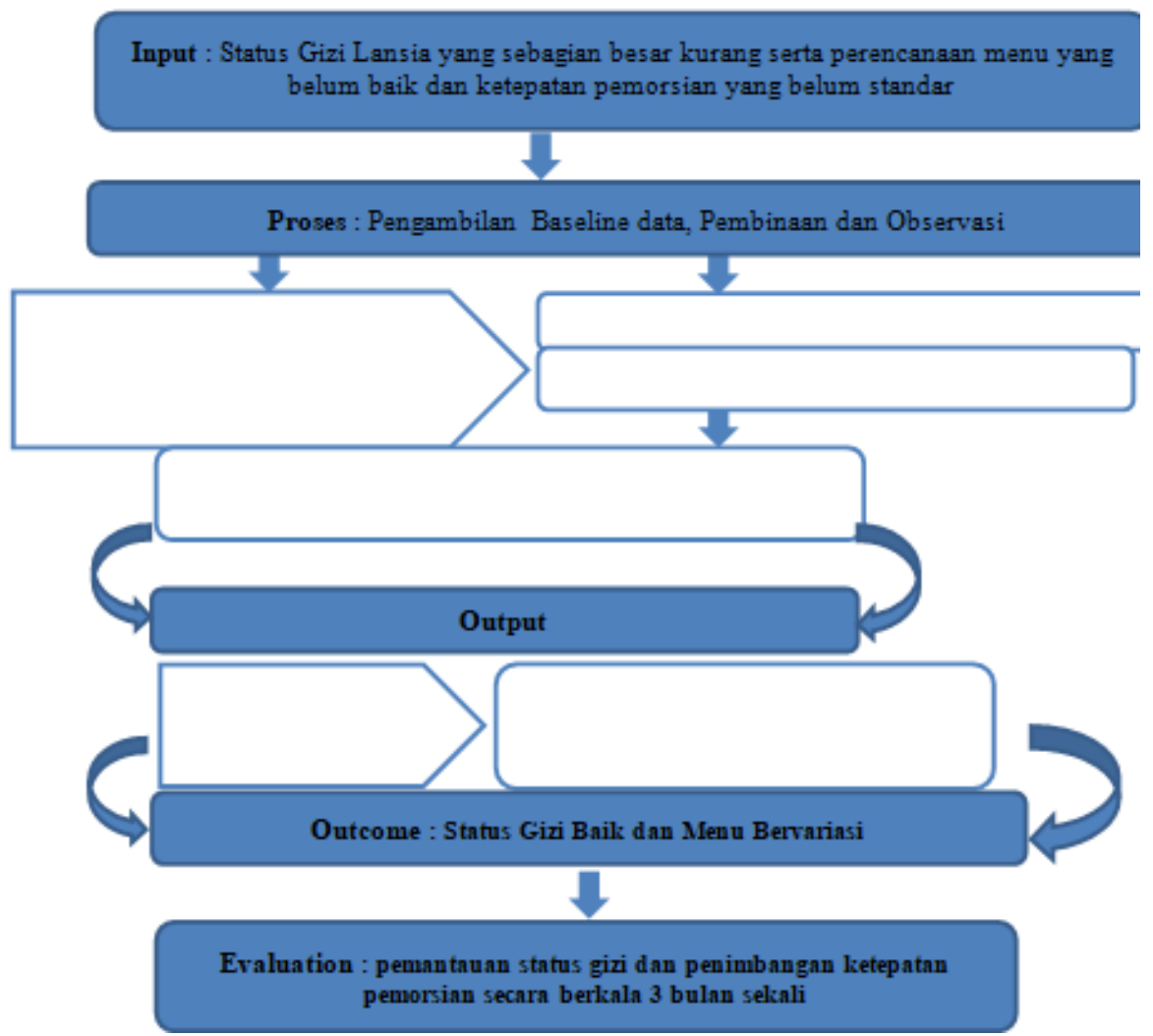

Gambar 1. Gambaran IPTEKS yang Ditransfer ke Mitra

Kegiatan ini dilakukan di panti pada bulan mei 2020, dengan mengumpulkan pengelola panti dan penjamah makanan sesuai dengan jadwal kegiatan yang telah disepakati.

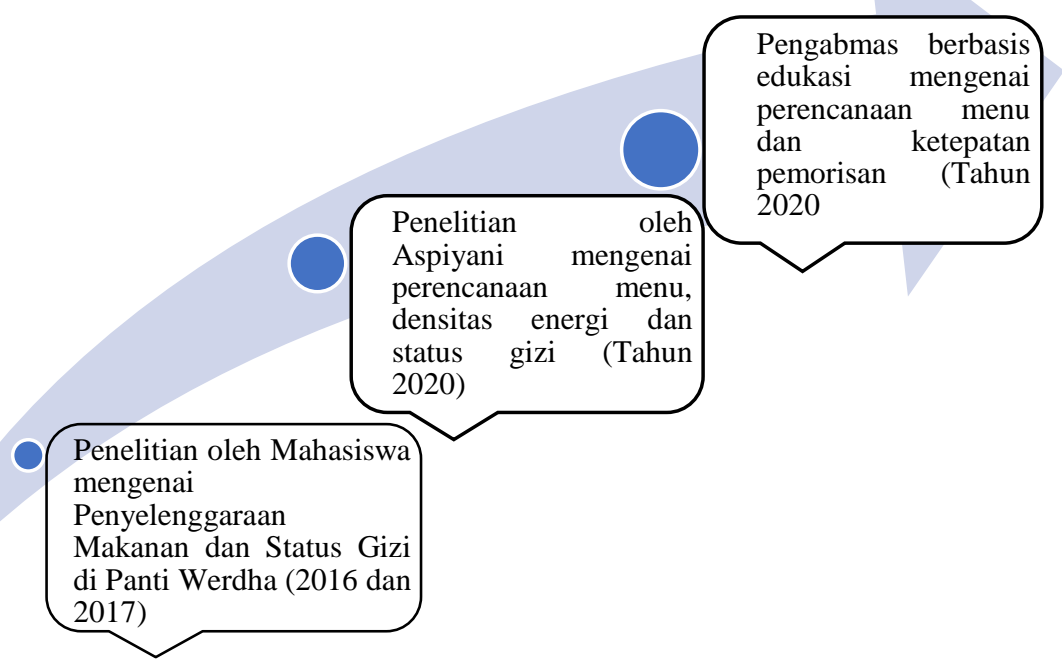

Gambar 2. Roadmap

\section{HASIL DAN PEMBAHASAN}

Kegiatan diawali dengan pembuatan perencanaan menu dengan beberapa alternatif menu bagi para lansia di panti sosial tersebut. Menu yang dibuat memperhatikan sasaran, yaitu lansia serta variasi menu, kebudayaan dan juga 
penetapan harga dari pihak panti. Proses penuaan pada lansia biasanya ditandai dengan peningkatan kehilangan otot, densitas tulang dan penurutan kualitas serta fungsi organ dan jaringan tubuh, seperti jantung, otak, ginjal, hari dan jaringan saraf. Berbagai permasalahan gizi dan keseharan yang dialami lansia terkait dengan penurunan berbagai fungsi organ dan jaringan, antara lain, hilangnya selera makan, menderita penyait degeneratif, tanggalnya gigi sehingga menyulitkan proses mengunyah, serta masalah kerapuhan tulang dan gigi. Mempertimbangkan berbagai keunikan dan permasalahan lansia di atas, kebutuhan gizi lansia berbeda dengan kebutuhan gizi orang dewasa. Pada umumnya kebutuhan akan energi semakin berkurang, sedangkan beberapa vitamin dan mineral yang dibutuhkan lebih banyak. Berikut adalah kebutuhan zat gizi harian Lansia dapat dilihat pada tabel 1.

Tabel 1. Kebutuhan Zat Gizi Harian Lansia

\begin{tabular}{lcc}
\hline Bahan Makanan & Laki-laki (2200 Kal) & Perempuan (1900 Kal) \\
\hline Nasi/penukar & 6 & 4,5 \\
Sayuran & 4 & 4 \\
Buah & 5 & 5 \\
Tempe/penukar & 3 & 3 \\
Ikan/penukar & 3 & 3 \\
Minyak/penukar & 6 & 4 \\
Gula & 2 & 2 \\
Susu rendah lemak & 1 & 1 \\
\hline
\end{tabular}

Sesuai dengan perhitungan kebutuhan tersebut, kami merancangkan menu untuk lansia di Panti Werdha dapat dilihat pada tabel 2.

Tabel 2. Rancangan Menu Penyelenggaraan Makanan Lansia

\begin{tabular}{|c|c|c|c|c|}
\hline Waktu makan & Hari 1 & Hari 2 & Hari 3 & Hari 4 \\
\hline Pagi 07.00 WIB & Bubur Manado & Kwetiau Siram Telur & Nasi Tim Ayam & Nasi Goreng Oriental \\
\hline $\begin{array}{c}\text { Selingan } 09.00 \\
\text { WIB }\end{array}$ & Singkong Thailand & Arem-arem & Salad buah saus jeruk & Kue lumpur topping ikan \\
\hline $\begin{array}{c}\text { Siang } 12.00 \\
\text { WIB }\end{array}$ & $\begin{array}{l}\text { Nasi Hainan } \\
\text { Ayam bakar } \\
\text { Tim tahu } \\
\text { Sayur pelangi }\end{array}$ & $\begin{array}{c}\text { Nasi Pelangi } \\
\text { Ikan Pepes Kemangi } \\
\text { Perkedel tempe } \\
\text { Sayur bening }\end{array}$ & $\begin{array}{c}\text { Nasi Ungu } \\
\text { Semur daging cincang } \\
\text { Pepes tahu } \\
\text { Tumis Sawi jagung }\end{array}$ & $\begin{array}{l}\text { Nasi bumbu jeruk } \\
\text { Telur bumbu kuning } \\
\text { Orak aarik tempe kc. } \\
\text { Pnjg } \\
\text { Sayur asem }\end{array}$ \\
\hline $\begin{array}{c}\text { Selingan } 16.00 \\
\text { WIB }\end{array}$ & $\begin{array}{l}\text { Semar mendem isi } \\
\text { ikan }\end{array}$ & Sago mangga & Sosis Solo & Cendol kuah soy bean \\
\hline $\begin{array}{c}\text { Malam } 19.00 \\
\text { WIB }\end{array}$ & $\begin{array}{l}\text { Nasi mix sayur } \\
\text { Telur bumbu } \\
\text { kuning } \\
\text { Tempe goreng } \\
\text { tepung } \\
\text { Tumis labu wortel }\end{array}$ & $\begin{array}{c}\text { Nasi mix sayur } \\
\text { Ayam filet bumbu } \\
\text { kemangi } \\
\text { Tahu kukus isi sayur } \\
\text { Cah sayur sawi }\end{array}$ & $\begin{array}{c}\text { Nasi mix jagung } \\
\text { Ikan bumbu saus } \\
\text { orange } \\
\text { Tempe penyet } \\
\text { Capcay }\end{array}$ & $\begin{array}{c}\text { Nasi gurih } \\
\text { Ayam goreng mentega } \\
\text { Tahu bumbu lada hitam } \\
\text { Sayur lodeh }\end{array}$ \\
\hline
\end{tabular}

Kombinasi bahan makanan yang bermacam-macam akan menciptakan variasi menu. Penyusunan variasi menu tersebut bertujuan untuk memuaskan konsumen [7]. Semakin bervariasi bahan makanan yang digunakan, maka semakin bervariasi pula menu yang dibuat. Semakin bervariasi menu yang disajikan, lansia akan merasa puas dan tidak bosan [8].

Susunan makanan sehari-hari untuk lansia juga hendaknya tidak terlalu banyak menyimpang dari kebiasaan makan. Pola makan disesuaikan dengan kecukupan gizi yang dianjurkan, dan menu makannya dapa disesuaikan dengan ketersediaan dan kebiasaan makan tiap daerah. Menu yang disusun sesuaikan dengan waktu makan yaitu untuk makan pagi, makan siang, makan malam, makan selingan dan lain-lain [9]. Selengkapnya dapat dilihat pada tabel 3.

Tabel 3. Rancangan Menu Penyelenggaraan Makanan Lansia (Alternatif Menu 2)

\begin{tabular}{clll}
\hline HARI & \multicolumn{1}{c}{ PAGI } & \multicolumn{1}{c}{ SIANG } & \multicolumn{1}{c}{ SORE } \\
\hline \multirow{2}{*}{ SENIN } & Nasi Tim campur & Nasi & Nasi \\
& Puding Mangga & Ikan Panggang saus jagung & Sop Wortel Daging Cincang \\
& Yogurt & Sup Tahu Sawi & Tempe Goreng \\
Energi : 2031.17 & Protein $: 76.38$ & Pepaya & Pastel isi kacang merah \\
& & Lemak 61.5
\end{tabular}




\begin{tabular}{|c|c|c|c|}
\hline \multirow{5}{*}{ SELASA } & Nasi Goreng sawi & Nasi & Nasi \\
\hline & Telur Dadar & Soto Ayam & Ikan Mas Pepes \\
\hline & Pancake Madu & & Tahu Goreng \\
\hline & & & Sayur Bayam Wortel \\
\hline & Buah Melon & Pisang Ambon & Roti Isi Kacang Hijau \\
\hline \multirow{3}{*}{ Energi : 1904.3} & Protein : 56.5 & Lemak : 51.8 & KH : 182.4 \\
\hline & Nasi & Nasi & Nasi \\
\hline & Sayur Sop Ayam & Sayur Sop Daging Cincang & Ayam Kecap \\
\hline \multirow[t]{2}{*}{ RABU } & Tempe Bacem & $\begin{array}{l}\text { Wortel } \\
\text { Semur Tahu }\end{array}$ & Tumis Buncis \\
\hline & Bubur Kacang Hijau & Semangka & Pastel Panggang \\
\hline \multirow[t]{3}{*}{ Energi : 1909.1} & Protein : 54.7 & Lemak 45.3 & $\mathrm{KH}: 247.5$ \\
\hline & Nasi & Nasi & Nasi \\
\hline & Sayur Bayam Wortel & Ikan Pindang Kembung & Ayam Semur \\
\hline \multirow[t]{3}{*}{ KAMIS } & Telur Puyuh & Tumis Sawi Putih & Cah Tempe Kacang Panjang \\
\hline & Lapis Tahu & Tahu Pepes & \\
\hline & Jus Melon & Pisang Ambon & Donat \\
\hline \multirow[t]{2}{*}{ Energi : 1880.3} & Protein : 47.6 & Lemak : 54.5 & $\mathrm{KH}: 275.6$ \\
\hline & Makaroni Schotel & Nasi & Nasi \\
\hline \multirow{3}{*}{ JUMAT } & Lapis Sayur & Ayam semur & Telur Dadar \\
\hline & Bubur Kacang Hijau & Tumis Kacang Panjang & Pepes Tahu kemangi \\
\hline & Pisang Ambon & Pepaya & Roti Isi Kacang Merah \\
\hline \multirow[t]{2}{*}{ Energi : 2001.5} & Protein : 70.8 & Lemak : 58.5 & KH : 285.65 \\
\hline & Nasi & Nasi & Nasi Tim Daging \\
\hline \multirow[t]{2}{*}{ SABTU } & Soto Banjar & $\begin{array}{l}\text { Ikan Bandeng Gula1 } \\
\text { Sayur Sop }\end{array}$ & Cah Tofu Buncis \\
\hline & $\begin{array}{l}\text { Pancake Madu } \\
\text { Jus Jambu Biji }\end{array}$ & Tempe Goreng & Pastel \\
\hline \multirow{3}{*}{ Energi : 1943.5} & Protein : 60.6 & Jemak $\cdot 576$ & $\mathrm{KH} \cdot 2436$ \\
\hline & 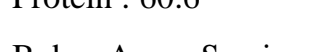 & Nasi & $1011.2+3.0$ \\
\hline & $\begin{array}{l}\text { Bubur Ayam Suwir } \\
\text { Bumbu Kuning }\end{array}$ & Ayam Bumbu Kuning & $\begin{array}{l}\text { Nasi } \\
\text { Orak Arik Telur }\end{array}$ \\
\hline \multirow{2}{*}{ MINGGU } & Kue Donat & Capcay & Cah Tempe Kacang Panjang \\
\hline & Jus Wortel & $\begin{array}{l}\text { Tahu Bacem } \\
\text { Semangka }\end{array}$ & Bubur Sumsum \\
\hline Energi : 1876.6 & Protein : 56.8 & Lemak : 65 & $\mathrm{KH}: 280.5$ \\
\hline
\end{tabular}

250 WBS Di Panti Sosial Tresna Werdha ditentukan harga makanan untuk setiap harinya rata-rata kurang lebih sebesar Rp.38.000,-/lansia. Jadi untuk pengeluaran belanja setiap hari yaitu sebesar Rp. 9.500.000/ hari untuk 250 WBS dengan pertimbangan zat gizi tetap terpenuhi sesuai kebutuhan dan lebih mengurangi anggaran. Piring makanku sebagai panduan anjuran konsumsi pangan setiap kali makan (meal), seperti disajikan pada gambar 3.
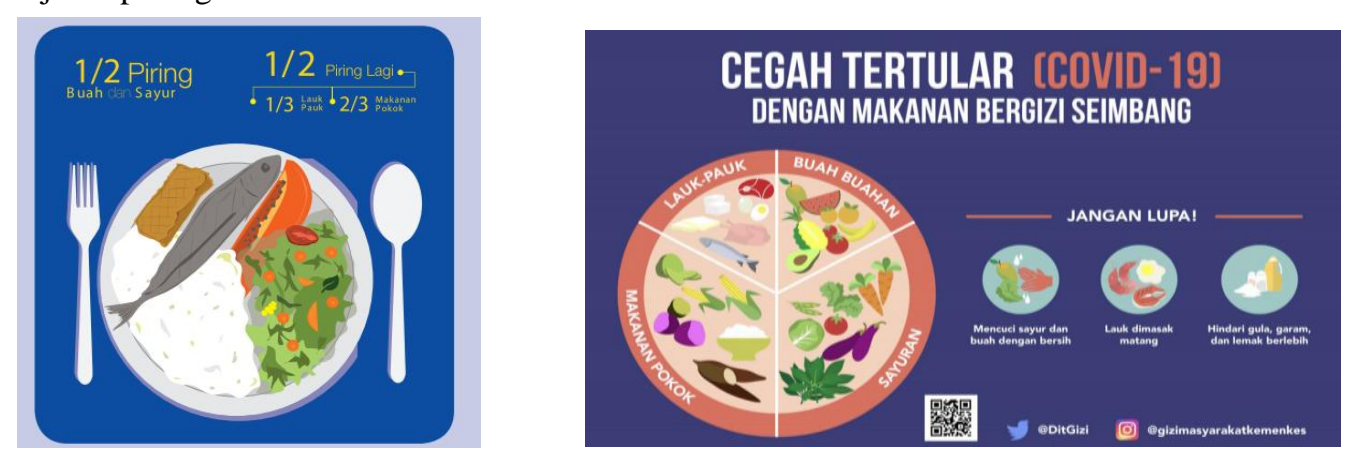

Gambar 3. Piring Makanku Bagi Lansia 

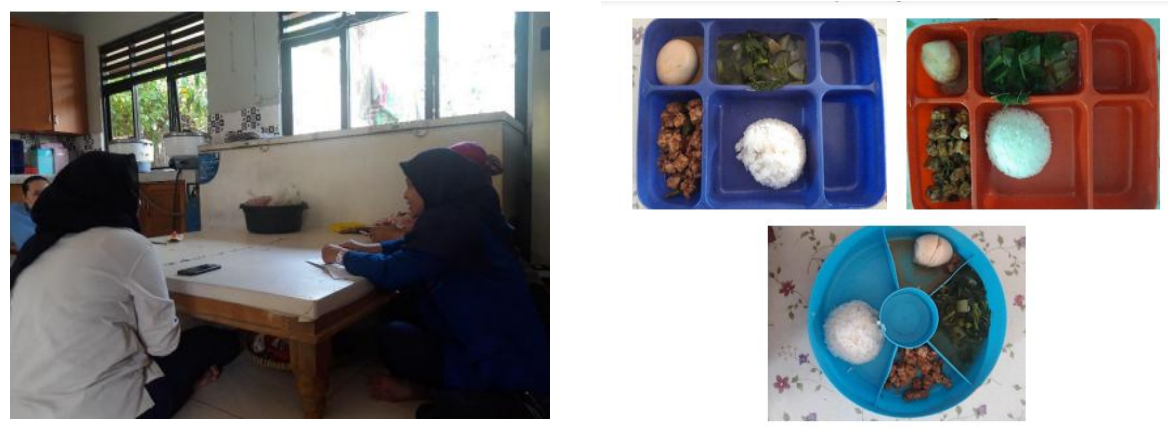

Gambar 4. Edukasi pada Penjamah Makanan dan Menu Di Panti

Pada lansia, komposisi menu yang diberikan sama dengan orang dewasa dengan proporsi, yaitu lebih dari total kebutuhan kalori berasal dari makanan pokok atau karbohidrat, sekitar $20 \%$ dari lemak, dan $15 \%$ dari protein, serta selebihnya vitamin dan mineral. Sumber karbohidrat yang digunakan dapat berupa nasi, sagu, jagung, atau umbi-umbian. Bahan makanan sumber protein seperti telur, daging, atau ikan. Sedangkan bahan makanan sumber lemak, bisa berupa minyak goreng, susu serta olahannya, daging, dan mentega.

Karbohidrat yang berasal makanan pokok normalnya dipakai tubuh untuk memberikan tenaga, sebagian lemak juga dibakar menjadi kalori yang lebih besar. 1 gram karbohidrat (nasi, jagung, dan ubi) dan protein (telur, daging dan ikan) menghasilkan 4 kalori. Sedang 1 gram lemak memberi tubuh 9 kalori. Artinya kalau komposisi menu harian menyimpang dari aturan, maka menu tersebut termasuk tidak seimbang. Misalnya apabila menu seseorang lebih berat kandungan lemaknya (produk susu, gorengan, dan jeroan). Akibatnya kalori yang tubuh terima cenderung berlebihan. Kalori yang berlebih akan disimpan di dalam hati dan di bawah kulit dalam bentuk lemak. Hal ini menyebabkan orang modern mengalami kelebihan berat badan dan lemak di organ tubuh lainnya, sehingga berdampak terhadap penyakit pembuluh darah dan jantung (gangguan ginjal, kanker, stroke, risiko serangan jantung, dan diabetes melitus).

Selain itu, menu untuk lansia harus lebih banyak mengandung cairan, dengan porsi yang lebih sedikit dibanding usia dewasa. Tetapi frekuensinya dapat diberikan lebih sering. Sebaiknya ada sumber kalsium, seperti ikan dan susu, untuk menjaga kepadatan tulang dan memperlambat risiko pengeroposan tulang. Serat juga harus ada, agar lansia tidak mengalami sembelit dan buang air besar menjadi lancar. Selain itu konsumsi air putih secukupnya, atau sekitar 1.500-1.600 mililiter per hari, atau setara dengan 6 gelas per hari, agar dapat mengurangi atau mencegah demensia dan mudah lupa. Di sisi lain, yang perlu dihindari adalah gula, garam, dan minyak dalam jumlah yang banyak.

Menu seimbang bagi lansia adalah susunan makanan yang mengandung cukup semua unsur zat gizi dibutuhkan lansia. Pedoman untuk makanan bagi lansia adalah makan makanan yang beraneka ragam dan mengandung zat gizi yang cukup, makanan mudah dicerna dan dikunyah, sumber protein yang berkualitas seperti susu, telur, daging dan ikan. Sebaliknya mengkonsumsi sumber karbohidrat kompleks, makanan sumber lemak harus berasal dari lemak nabati, mengkonsumsi sumber zat besi seperti hati, daging, ikan, kacang-kacangan dan sayuran daun hijau [3]. Adapun sebagai media yang diberikan berupa cakram siklus menu untuk lansia di panti werdha dapat dilihat pada gambar 5.
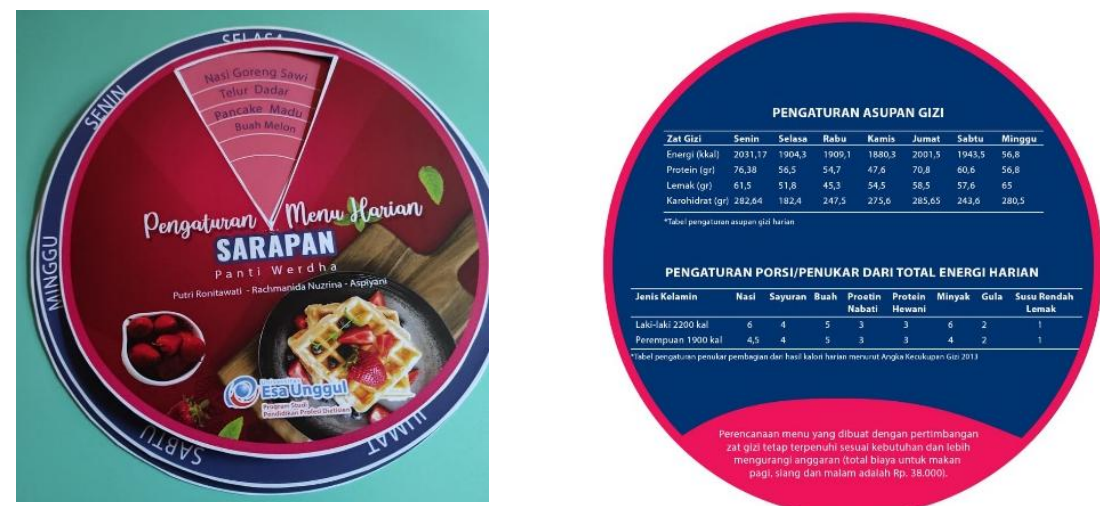

Gambar 5. Cakram Gizi Menu Sarapan dan Total Kebutuhan Di Panti Werdha 

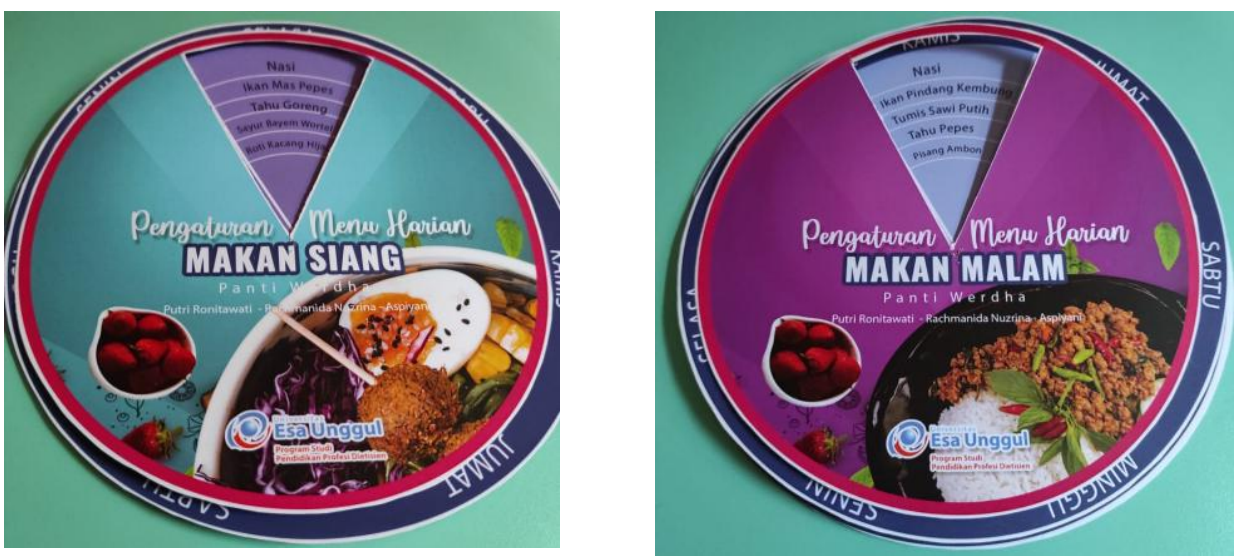

Gambar 6. Cakram Gizi Menu Makan Siang dan Makan Malam Di Panti Werdha

Tujuan penyelenggaraan makan di panti werdha adalah menyediakan makanan yang bergizi yang dapat memenuhi kebutuhan gizi lansia. Jika penyelenggaraan makan di panti tidak diatur dengan baik, maka sumber daya yang tersedia untuk lansia tidak dapat dimanfaatkan secara optimal. Oleh karena itu, penyelenggaraan makan di panti werdha sebaiknya dilaksanakan secara efisien, agar mencapai tujuan yang terwujud dalam penyajian porsi yang tepat kepada lansia [10].

\section{KESIMPULAN}

Melalui kegiatan program pengabdian masyarakat ini secara langsung dapat meningkatkan pengetahuan pengelola panti dan para penjamah makanan, menu makanan lansia yang bervariasi dan porsi makanan yang tepat sehingga status gizi lansia menjadi baik. Melalui pembinaan ini juga, agar tercipta penyelenggaraan makanan institusi yang sesuai standar sehingga dapat menghasilkan makanan yang baik dari segi kuantitas dan kualitas dalam memenuhi kebutuhan gizi lansia di panti tersebut.

Penelitian lanjutan perlu dilakukan dengan menggunakan beberapa metode edukasi lainnya untuk memperoleh hasil yang optimal dalam meningkatkan pengetahuan pengelola panti dan penjamah makanan mengenai perencanaan menu gizi seimbang bagi lansia. Diharapkan dapat memperbaiki status gizi dan kesehatan lansia.

\section{DAFTAR PUSTAKA}

[1] I. S. Wahyuni, "Hubungan Antara Pengetahuan dan Sikap Terhadap Perilaku Gizi Seimbang pada Lansia Panti Werda Pucang Gading Semarang,” 2011.

[2] A. P. Ariani, Ilmu Gizi. Yogyakarta: Nuha Medika, 2017.

[3] M. Almatsier, S, Soetarjo, S, Seokarti, Gizi Dalam Daur Kehidupan. Jakarta: Gramedia Pustaka Utama, 2011.

[4] M. B. Arisman, Buku Ajar Ilmu Gizi dalam Daur Kehidupan Edisi 2. Jakarta: Buku Kedokteran EGC, 2009.

[5] Nugroho, Keperawatan Gerontik dan Geriatrik. Jakarta: Buku Kedokteran EGC, 2008.

[6] A. Istiany and Rusilanti, "Gizi Lansia," in Gizi Terapan, E. Kuswandi, Ed. Bandung: PT REMAJA ROSDAKARYA, 2013, p. 214.

[7] D. Sutanti, "Penyelenggaraan Makan untuk Taruna di Akademi Militer," Universitas Negeri Yogyakarta, 2014.

[8] L. K. Tanuwijaya, T. D. Novitasari, E. P. Arfiani, Y. Wani, and D. E. Wulandari, "Kepuasan Pasien Terhadap Variasi Bahan Makanan di Rumah Sakit," J. Gizi, vol. 8, no. 1, pp. 50-58, 2019, [Online]. Available: https://www.researchgate.net/publication/326122173_Sisa_Makanan_Pasien_Rawat_Inap_Analisis_Kualitatif/do wnload.

[9] I. Tamba and A. C. H. Gultom, "Tingkat Selera Makan Lansia Di Panti Werdah Yayasan Guna Budi Bakti Medan Labuhan," J. Saintika, vol. 14, no. 2, pp. 161-172, 2014.

[10] D. N. Cendanawangi, T. Tjaronosari, and I. R. Palupi, "Ketepatan porsi berhubungan dengan asupan makan pada lanjut usia di Panti Sosial Tresna Werdha Budi Luhur, Bantul, Yogyakarta," J. Gizi dan Diet. Indones. (Indonesian J. Nutr. Diet., vol. 4, no. 1, p. 8, 2016, doi: 10.21927/ijnd.2016.4(1).8-18. 
